strong links will doubtless be forged between the two centres and the pre-eminence will ultimately depend on the mark each of them makes on medical research.

\section{REGIONAL DEVELOPMENT}

\section{Integrate and Expand}

\section{from our Special Correspondent}

\section{Thurso, Caithness, October}

Caltinness, in the north of Scotland, scems happily to have accommodated the nuclear rescarch workers and their camp-followers who have been settling here since 1955, when work began on the fast breeder reactor at Dounreay. In the decade to 1964, the population of Thurso alone has increased from 3,800 to 9,750. By all accounts, the coming of the "atomics" has created in the area a community which shows none of the problems of settling down usually associated. with similar developments, such as the new towns near London.

The county itself is flat and treeless, lying beyond the Highlands, and this is enough to set it apart from the rest of Scotland. Isolation and the sparse population--22,000 before Dounreay-were strong points in favour of the decision to build the experimental reactor establishment there. At the time, however, it could hardly have been foreseen that the farming and fishing community would so easily absorb the influx from the south.

Housing had to be provided quickly. The first outsiders were accommodated on a housing estate at the edge of Thurso. The Atomic Energy Authority bought the land and built the houses, which it rented out. Two more estates soon followed. At present, more than a thousand people from outside Caithness are living in the county and working at the Dounreay establishment, and these, together with their families, account for most of the growth of the population. Thurso, in other words, has taken the main weight of the development.

It remains, however, one town. There is apparently no antagonism between the old and the new, and no evidence of two sides at war over local policy. The "atomics" as a separate class have virtually ceased to exist.

Quite apart from an evidently inborn hospitality, the worry about the continuing depopulation of the Highlands has clearly made the newcomers welcome. It was becoming increasingly difficult to sustain an economically self-supporting community on the basis of a declining agriculture. As a result of Dounreay, Caithness is one of the few areas in the north of Scotland which have not suffered from a falling population over the past twenty years.

Local authorities have willingly provided big developments on their own account, including new council houses alongside one of the AEA's estates and a rationalization of the school system, with many children from outlying villages now educated in modern primary and secondary schools at Thurso and Wick. The largest project has been Thurso Technical College, which since 1959 has provided science and engineering courses up to HNC level linked with the AEA's apprentice training scheme, as well as secretarial classes and an evening adult education programme. The principal has also offered to provide training facilities for future industrial expansion as the need arises.

The willingness of the Dounreay workers to involve themselves in local activities has been helpful. The main social club on one of the AEA estates has a large number of associate members from the old town, the local churches have larger congregations, and the Philosophical Society is apparently thriving as never before.

Another difficulty resolved centres on the American staff of the NATO carly-warning station, on the coast noar the nuclear establishment. There are nearly a hundred of these, who brought their own prefabricated homes with them and erected them in Thurso. Even though they are drafted there for periods of only three or four years, they seem to be as happily settled in as the rest.

As things are, however, the future is not all optimistic. The future of Dounreay itself is in doubt, while unemployment is already nine per cent. In spite of assurances that there will be little change for the next five years, the facts seem to be that when the Prototype Fast Reactor is complete in 1972, fewer people will be required to run it; and that the original experimental fast reactor will sooner or later outlive its usefulness. It is, of course, argued that, having brought about economic changes on such a scale, the Ministry of Technology should be responsible for keeping things going, perhaps by bringing in new research programmes. Whether this will actually be the case is another matter. Some redundancies seem inevitable, and in this situation the contentment of the new community may ironically prove to be a disadvantage, because there will be a surplus of technically qualified workers who quite openly admit that they do not want to return. south.

The chosen solution is to attract more light industry into the county. An exceptionally active county development officer is now campaigning for this, supported by the enthusiasm of the local councils and the financia] powers of the Highlands and Islands Development Board, which can provide grants and loans to new industry. Much of the effort goes into selling the new image of Caithness as a place where people want to live, because only in this way can the traditional ideas of inaccessibility be overcome.

So far, the rate of growth has been slow. Caithness has not benefited as much as counties farther south from the Development Board's money, which in 1965-68 amounted to more than $£ 1$ million for manufacturing industry. The largest concern at the moment is Caithness Glass Ltd, with eighty employees producing glassware for a wide market. $\Lambda$ plastics factory, originating through the needs of Dounreay, now makes protective garments for the AEA as a whole. There is very little else.

There is, however, plenty of land. Caithness County Council owns a site at a disused RAF station in Wick which has the advantage of containing buildings in a state suitable for conversion to factories. Part of this has been allocated already to a firm making scientific instruments, and another section is set aside for an intensive farming unit. The future of the county may in the end depend on what comes of plans to develop the port of Scrabster, near Thurso, which could easily be converted into a deep-water harbour. There is also the possibility of new ferry services for vehicles to Orkney and Shetland or even Norway. 